\title{
Germination and antioxidant action in melon seeds exposed to salt stress ${ }^{1}$
}

\author{
Daniel Teixeira Pinheiro², Aparecida Leonir da Silva ${ }^{3}$, \\ Laércio Junio da Silva ${ }^{2}$, Marcelo Coelho Sekita ${ }^{4}$, Denise Cunha Fernandes dos Santos Dias ${ }^{2}$
}

\section{ABSTRACT}

Salinity influences all germination stages and may adversely affect the seedlings establishment in the field. This study aimed at assessing the effects of salt stress on the physiological potential of melon (Cucumis melo L.) seeds. Germination and activity of superoxide dismutase (SOD), catalase (CAT) and peroxidase (POX) enzymes were assessed at the osmotic potentials of $0.0 \mathrm{MPa},-0.1 \mathrm{MPa}$, -0.2 MPa, -0.3 MPa, -0.4 MPa and -0.5 MPa. The enzymatic activity was assessed after $24 \mathrm{~h}, 48 \mathrm{~h}$ and $72 \mathrm{~h}$ of imbibition. Seed germination was zero at $-0.5 \mathrm{MPa}$ and $91 \%$ and $85 \%$ at $-0.1 \mathrm{MPa}$ and $-0.2 \mathrm{MPa}$, respectively. In general, the activity of SOD, CAT and POX enzymes increased with the salt-induced stress, in the different times of imbibition, and these increases were more evident at $-0.4 \mathrm{MPa}$ and $-0.5 \mathrm{MPa}$. The salt stress induced by $\mathrm{NaCl}$ diminishes the germination rate of melon seeds, particularly from the osmotic potential of $-0.2 \mathrm{MPa}$. There is a significant increase in the activity of SOD, CAT and POX enzymes, mainly after $48 \mathrm{~h}$ of exposure.

KEY-WORDS: Cucumis melo L.; enzymes; salinity; sodium.

\section{INTRODUCTION}

Germination starts when the seed absorbs water and culminates in several cellular processes that will allow the embryo to grow and develop (Marcos-Filho 2015). This process involves complex cellular changes, among them protein hydration, increased respiration, macromolecule synthesis and cell elongation (Bewley et al. 2013). It is considered a fundamental and vital stage of the plants growth, determining the crop establishment and yield in the field (Hasanuzzaman et al. 2013).

\section{RESUMO}

Germinação e ação antioxidante em sementes de melão submetidas a estresse salino

A salinidade tem influência em todas as etapas da germinação e pode afetar consideravelmente o estabelecimento de plântulas em campo. Objetivou-se avaliar os efeitos do estresse salino no potencial fisiológico de sementes de melão (Cucumis melo L.). Foram avaliadas a germinação e a atividade das enzimas superóxido dismutase (SOD), catalase (CAT) e peroxidase (POX), nos potenciais osmóticos de $0,0 \mathrm{MPa} ;-0,1 \mathrm{MPa}$; -0,2 $\mathrm{MPa}$; -0,3 MPa; -0,4 Mpa; e -0,5 MPa. A atividade enzimática foi avaliada após 24 h, 48 h e 72 h de embebição. A germinação das sementes foi nula no potencial de $-0,5 \mathrm{MPa}$ e de $91 \%$ e $85 \%$, respectivamente nos potenciais de -0,1 MPa e -0,2 MPa. De maneira geral, a atividade das enzimas SOD, CAT e POX aumentou com a indução do estresse salino, nos diferentes tempos de embebição, sendo que esses aumentos foram mais evidentes nos potenciais de - $0,4 \mathrm{MPa} \mathrm{e}$ $-0,5 \mathrm{MPa}$. O estresse salino induzido por $\mathrm{NaCl}$ reduz a germinação de sementes de melão, principalmente a partir do potencial de $-0,2 \mathrm{MPa}$. Ocorre aumento significativo na atividade das enzimas SOD, CAT e POX, principalmente após 48 h de exposição.

PALVARAS-CHAVE: Cucumis melo L.; enzimas; salinidade; sódio.

The osmotic potential of pure water is close to $0.0 \mathrm{MPa}$, and its movement is always toward a lower or more negative potential, which in turn is directly influenced by the presence of salts (Blum 2011). Thus, the primary effect of salinity is a reduced osmotic potential in the environment, affecting the water uptake and overall germination process (Soares et al. 2015).

At high levels, salinity may cause toxic effects due to ions accumulation. Ion toxicity, during the germination process, causes diverse physiological and biochemical disorders, such as hormonal imbalance and reduced use of reserves (Yacoubi et al. 2013).

1. Manuscript received in Mar./2016 and accepted for publication in Sep./2016 (http://dx.doi.org/10.1590/1983-40632016v4640431).

2. Universidade Federal de Viçosa, Centro de Ciências Agrárias, Departamento de Fitotecnia, Viçosa, MG, Brazil.

E-mails: pinheiroagroufv@gmail.com, laerciojdsilva@gmail.com,dcunhadias@gmail.com.

3. Universidade de São Paulo, Escola de Agricultura "Luiz de Queiroz”, Piracicaba, SP, Brazil. E-mail: aparecidaleonir@gmail.com.

4. Grupo Sekita, São Gotardo, MG, Brazil.E-mail: marcelosekita@yahoo.com.br. 
Changes in cellular homeostasis, due to high salt concentrations, may lead to the production of reactive oxygen species at toxic levels for the cells, among them superoxide radical $\left(\mathrm{O}_{2}^{-}\right)$and hydrogen peroxide $\left(\mathrm{H}_{2} \mathrm{O}_{2}\right)$. The accumulation of reactive oxygen species causes oxidation of membrane lipids, proteins and nucleic acids, and may lead to cell death (Yao et al. 2012).

Antioxidant enzymes such as superoxide dismutase (SOD), catalase (CAT) and peroxidase (POX) are some of the main mechanisms that perform important functions in the elimination and neutralization of reactive oxygen species produced under salt stress (Seckin et al. 2010).

The effects of salt stress on the germination rate and development of melon (Cucumis melo L.) and other cucurbits have already been reported (Keling et al. 2013, Zhang et al. 2014, Dantas et al. 2015). However, these mechanisms of tolerance, in general, are poorly understood, if compared to the information available on adult plants, and may vary according to a series of factors that are inherent to the species and environment (Zhang et al. 2012, Das 2013).

This study aimed at assessing the effects of salt stress on the physiological quality and antioxidant enzymes activity in melon seeds.

\section{MATERIAL AND METHODS}

The study was conducted at the Universidade Federal de Viçosa, in Viçosa, Minas Gerais State, Brazil. Seeds of the hybrid yellow melon (Cucumis melo var. inodorus) Diplomata $\mathrm{F}_{1}$, produced by Agristar Brasil Ltda., were used.

For the germination assessment, the seeds were spread on paper towel rolls moistened with solutions of sodium chloride $(\mathrm{NaCl})$, at osmotic potentials of 0.0 MPa, -0.1 MPa, -0.2 MPa, -0.3 MPa, -0.4 MPa and $-0.5 \mathrm{MPa}$ and electric conductivity of $0.0 \mathrm{dS} \mathrm{m}^{-1}$, $2.8 \mathrm{dS} \mathrm{m}^{-1}, 5.6 \mathrm{dS} \mathrm{m}^{-1}, 8.3 \mathrm{dS} \mathrm{m}^{-1}, 11.2 \mathrm{dS} \mathrm{m}^{-1}$ and $14.0 \mathrm{dS} \mathrm{m}^{-1}$, respectively. The solution volume corresponded to 2.5 times the dry paper weight. In the control treatment $(0.0 \mathrm{MPa})$, only distilled water was used. The rolls were maintained in a germination chamber, at $25^{\circ} \mathrm{C}$, and the results were expressed in percentage of normal seedlings grown at the eighth day after sowing (Brasil 2009).

The first germination count was made along with the germination test, consisting of the percentage of normal seedlings grown at the fourth day after sowing.

For analysis of the activity of the antioxidant enzymes, the seeds were put to germinate in $\mathrm{NaCl}$ solutions, at the same osmotic potentials described for the germination test. After $24 \mathrm{~h}, 48 \mathrm{~h}$ and $72 \mathrm{~h}$ of sowing, the embryos (cotyledons and embryonic axes) were extracted, frozen in liquid nitrogen and stored at $-20^{\circ} \mathrm{C}$, until the date of assessment.

To determine the activity of the antioxidant enzymes superoxide dismutase (SOD), catalase (CAT) and peroxidases (POX), crude enzyme extracts were obtained by macerating $0.3 \mathrm{~g}$ of the embryos in liquid nitrogen, followed by the addition of $2 \mathrm{~mL}$ of the extraction medium, potassium phosphate buffer $(0.1 \mathrm{M}, \mathrm{pH} 6.8)$, containing $0.1 \mathrm{mM}$ of ethylenediaminetetraacetic acid (EDTA), $1.0 \mathrm{mM}$ of phenylmethanelsulfonyl fluoride (PMSF) and $1 \%$ $(\mathrm{p} / \mathrm{v})$ of polyvinylpolypyrrolidone (PVPP) (Peixoto et al. 1999). The homogenate (a.e. 19,000 g) was centrifuged during $15 \mathrm{~min}$, at $4{ }^{\circ} \mathrm{C}$.

The SOD activity was determined by adding $50 \mu \mathrm{L}$ of the crude enzyme extract to $2.95 \mathrm{~mL}$ of reaction medium, consisting of $50 \mathrm{mM}$ of sodium phosphate, at $\mathrm{pH} 7.8$, containing $13 \mathrm{mM}$ of methionine, $75 \mu \mathrm{M}$ of p-nitro blue tetrazolium (NBT), $0.1 \mathrm{mM}$ of EDTA and $2 \mu \mathrm{M}$ of riboflavin (Del Longo et al. 1993). The reaction was carried out at a temperature of $25^{\circ} \mathrm{C}$, in a reaction chamber equipped with a $15-\mathrm{W}$ fluorescent lamp. After $5 \mathrm{~min}$ of exposure to the light, the lamp was turned off, and the blue formazan, which was produced by the photo reduction of NBT, was measured by absorbance at $560 \mathrm{~nm}$. The absorbance value of the reaction medium, which was the same as the previous one, but maintained in the dark for the same period, served as blank and was subtracted from the result of each sample that received light (Giannopolitis \& Ries 1977). One SOD unit was defined as the amount of enzyme required to inhibit the NBT photo-reduction by $50 \%$ (Beauchamp \& Fridovich 1971). The result was expressed in $U \min ^{-1} \mu \mathrm{g}^{-1}$ of protein.

The CAT activity was determined by the addition of $50 \mu \mathrm{L}$ of the crude enzyme extract to $2.95 \mathrm{~mL}$ of the reaction medium, consisting of $50 \mathrm{mM}$ of potassium phosphate buffer at $\mathrm{pH}$ 7.0, and $12.5 \mathrm{mM}$ of $\mathrm{H}_{2} \mathrm{O}_{2}$ (adapted from Havir \& McHale 1987). The absorbance decrease at $240 \mathrm{~nm}$ and $25{ }^{\circ} \mathrm{C}$ was measured during the first minute of reaction. The enzyme activity was calculated using 
the molar extinction coefficient of $36 \mathrm{M}^{-1} \mathrm{~cm}^{-1}$ (Anderson et al. 1995), and the result was expressed

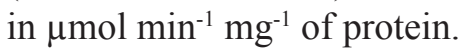

The POX activity was determined by adding $30 \mu \mathrm{L}$ of the crude enzyme extract to $2.97 \mathrm{~mL}$ of the reaction medium, comprised of $25 \mathrm{mM}$ of potassium phosphate buffer at $\mathrm{pH} 6.8,20 \mathrm{mM}$ of pyrogaloll and $20 \mathrm{mM}$ of $\mathrm{H}_{2} \mathrm{O}_{2}$ (adapted from Kar \& Mishra 1976). The production of purpurogallin was measured by the absorbance increase at $420 \mathrm{~nm}$ and temperature of $25^{\circ} \mathrm{C}$. The enzyme activity was calculated using the molar extinction coefficient of $2.47 \mathrm{M}^{-1} \mathrm{~cm}^{-1}$ (Chance \& Maehley 1955), and the result was expressed in $\mu \mathrm{mol} \mathrm{min} \mathrm{mg}^{-1}$ of protein.

The protein content was determined by using bovine serum albumin (BSA) as standard (Bradford 1976). A total of $50 \mu \mathrm{L}$ of the enzyme extract was added to $1 \mathrm{~mL}$ of Bradford reagent, followed by stirring. After $20 \mathrm{~min}$, the sample absorbance was read on a spectrophotometer, at $595 \mathrm{~nm}$.

The physiological quality of the melon seeds was measured in a completely randomized design, with six treatments $(0.0 \mathrm{MPa},-0.1 \mathrm{MPa},-0.2 \mathrm{MPa}$, $-0.3 \mathrm{MPa},-0.4 \mathrm{MPa}$ and $-0.5 \mathrm{MPa}$ ) and eight replications. Each experimental unit was comprised of 25 seeds. Data were subjected to analysis of variance and means were adjusted to regression equations. Coefficients of regression were determined by the t-test, at $1 \%$ and $5 \%$.

The enzyme analysis was conducted in a completely randomized factorial design, with six osmotic potentials $(0.0 \mathrm{MPa},-0.1 \mathrm{MPa},-0.2 \mathrm{MPa}$, $-0.3 \mathrm{MPa},-0.4 \mathrm{MPa}$ and $-0.5 \mathrm{MPa}) \mathrm{x}$ three imbibition times $(24 \mathrm{~h}, 48 \mathrm{~h}$ and $72 \mathrm{~h}$ ) and four replications.
Data were subjected to analysis of variance and represented by mean \pm standard deviation.

\section{RESULTS AND DISCUSSION}

The percentage of normal seedlings was zero at the osmotic potential of $-0.5 \mathrm{MPa}$ (Figure 1). In the first germination count (Figure 1a) and in germination (Figure 1b), the seeds that were subjected to the osmotic potential of $-0.4 \mathrm{MPa}$ exhibited reductions of approximately 90 percentage points (p.p.), if compared to the control $(0.0 \mathrm{MPa})$. The germination percentages obtained for the osmotic potentials of $0.0 \mathrm{MPa},-0.1 \mathrm{MPa}$ and $-0.2 \mathrm{MPa}$ were similar, with a sharper decline from $-0.2 \mathrm{MPa}$ to $-0.3 \mathrm{MPa}$ (Figure 1b). By comparing these data with the first count (Figure 1a), which is an indicator of the germination velocity (Nakagawa 1999), it can be observed that this characteristic was more affected at $-0.2 \mathrm{MPa}$ and lower.

For the osmotic potentials of $-0.1 \mathrm{MPa}$ and $-0.2 \mathrm{MPa}$, the first count values were $84 \%$ and $66 \%$, respectively (Figure 1a), while the germination percentages were $91 \%$ and $85 \%$, respectively (Figure 1b).

For osmotic potentials approaching $0.0 \mathrm{MPa}$, the rate of germination declined, due to a decrease in water uptake, followed by a limited hydrolysis of the reserves and translocation of these reserves to the embryonic axis (Wahid et al. 2011). However, as the osmotic potential becomes more negative, the deleterious effects of $\mathrm{NaCl}$ are associated with the amount of $\mathrm{Na}^{+}$ions absorbed, which exceeds the capacity of cytoplasm extrusion and/or the
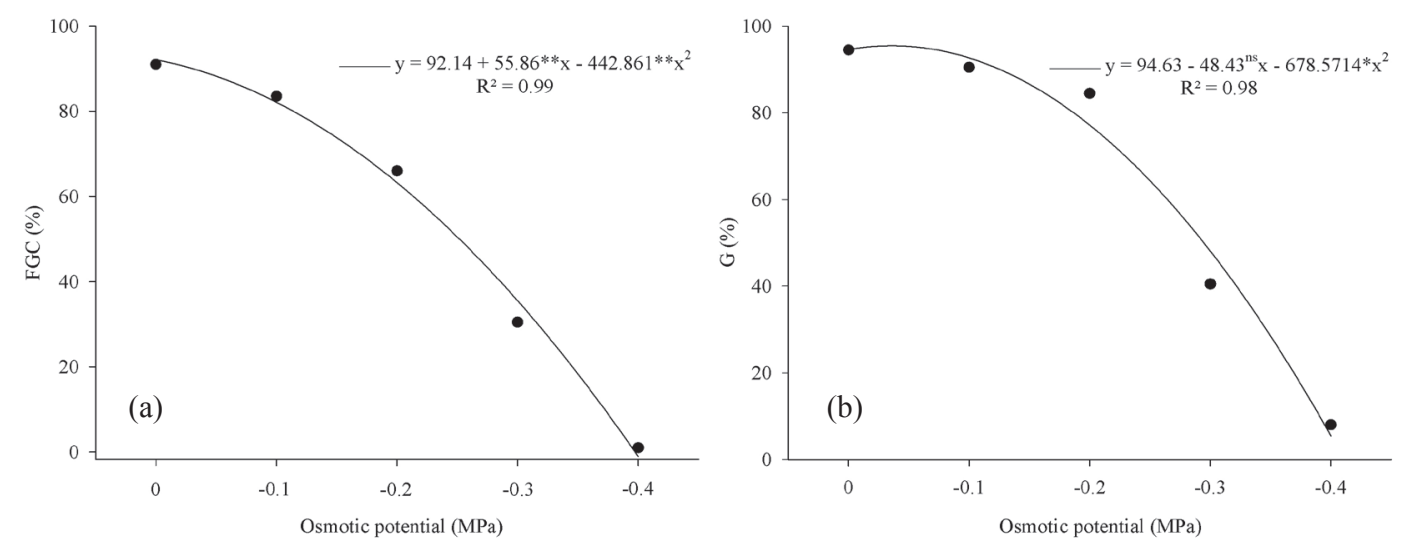

Figure 1. Germination rate of melon seeds exposed to salt stress. (a) First germination count (FGC); (b) germination (G). ** and *: significant at $1 \%$ and $5 \%$, by the t-test, respectively. 
compartmentation in the vacuoles (Läuchli \& Grattan 2007).

In this context, Torres et al. (2000), Torres (2007) and Secco et al. (2010) observed deleterious effects of $\mathrm{NaCl}$ (especially at $-0.4 \mathrm{MPa}$ ) in seeds of cucumber, watermelon and melon, respectively. Thus, it can be seen that the Diplomata $\mathrm{F}_{1}$ hybrid is sensitive to salt stress, based on the fact that more substantial reductions in the percentage of normal seedlings, as obtained in the first germination count, were found at $-0.1 \mathrm{MPa}$ and lower (Figure 1a) and at $-0.2 \mathrm{MPa}$ in germination (Figure $1 \mathrm{~b}$ ).

In general, there was an increase of SOD, CAT and POX enzymes with the induction of salt stress in different imbibition times, particularly at $-0.4 \mathrm{MPa}$ and $-0.5 \mathrm{MPa}$ (Figures 2, 3 and 4). Relating these results to germination, it is known that water uptake by seeds is essential for the antioxidant enzymes activity, but, at the same time, it activates, in seeds under stress, diverse metabolic pathways that contribute to the generation and accumulation of reactive oxygen species, negatively affecting the germination process (Yao et al. 2012). Thus, the low percentage of seed germination, concomitantly to an enhanced enzymes activity at $-0.4 \mathrm{MPa}$ and $-0.5 \mathrm{MPa}$, can be explained.

The SOD activity was greater at $0.0 \mathrm{MPa}$, $-0.1 \mathrm{MPa},-0.2 \mathrm{MPa}$ and $-0.3 \mathrm{MPa}$, after $24 \mathrm{~h}$ and $48 \mathrm{~h}$ of imbibition (Figure 2). SOD acts in the first line of defense against reactive oxygen species, by dismutating superoxide radicals $\left(\mathrm{O}_{2}^{-}\right)$to hydrogen peroxide $\left(\mathrm{H}_{2} \mathrm{O}_{2}\right)$ (Harter et al. 2014). Thus, the reduced activity of this enzyme may be associated

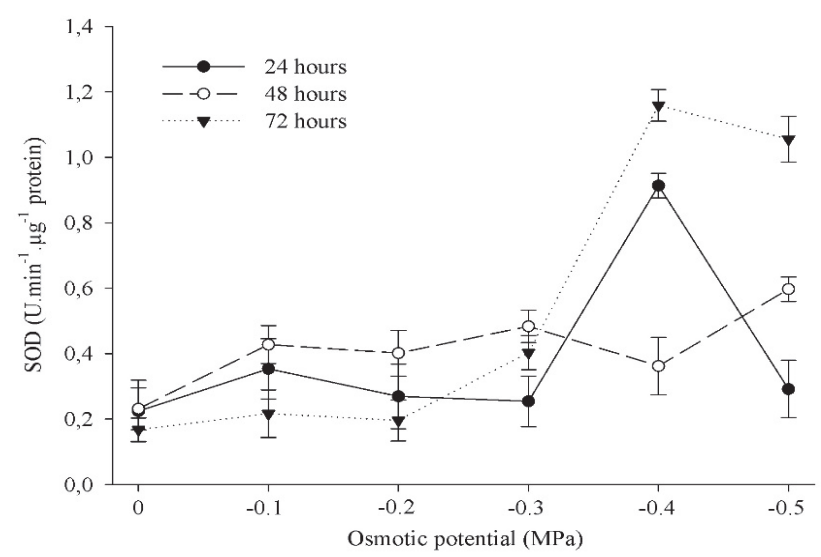

Figure 2. Activity of superoxide dismutase (SOD) in melon seeds exposed to salt stress at different osmotic potentials and imbibition times. Bars: standard deviation. with $\mathrm{H}_{2} \mathrm{O}_{2}$ accumulation, which, at the same time, activates peroxidases (Sivritepe et al. 2008).

There was a sharp increase in the SOD activity at $-0.4 \mathrm{MPa}$, followed by reductions at $-0.5 \mathrm{MPa}$, after $24 \mathrm{~h}$ and $72 \mathrm{~h}$ of imbibition (Figure 2). Since it is the lowest osmotic potential examined, $-0.5 \mathrm{MPa}$ was the potential that inhibited most the water uptake by the seeds. According to Celikkol-Akcay et al. (2010), this low availability of water added to a high production of reactive oxygen species may lead to oxidation and inactivation of antioxidant enzymes, such as SOD.

These results corroborate those observed by Fan et al. (2013), who examined the effect of salt stress on cucumber seeds and attributed a key role to SOD as an antioxidant defense mechanism. On

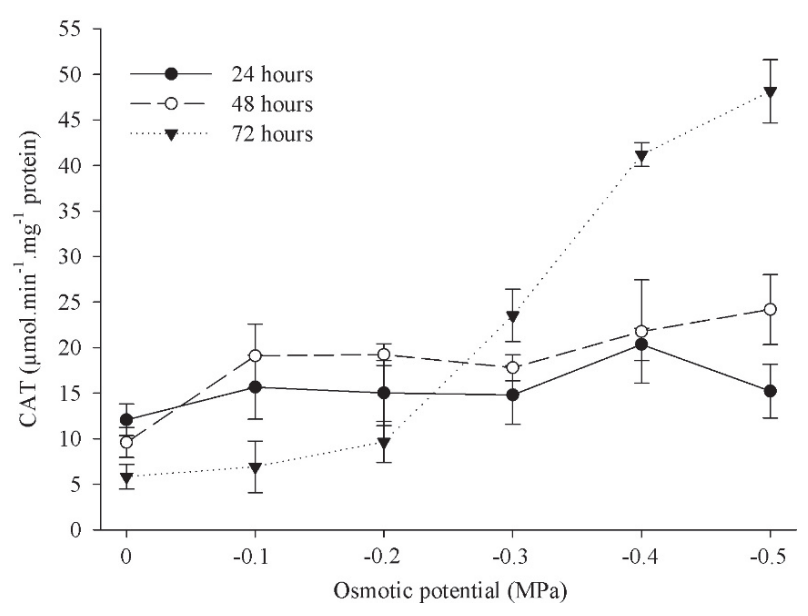

Figure 3. Catalase (CAT) activity in melon seeds exposed to salt stress at diverse osmotic potentials and imbibition times. Bars: standard deviation.

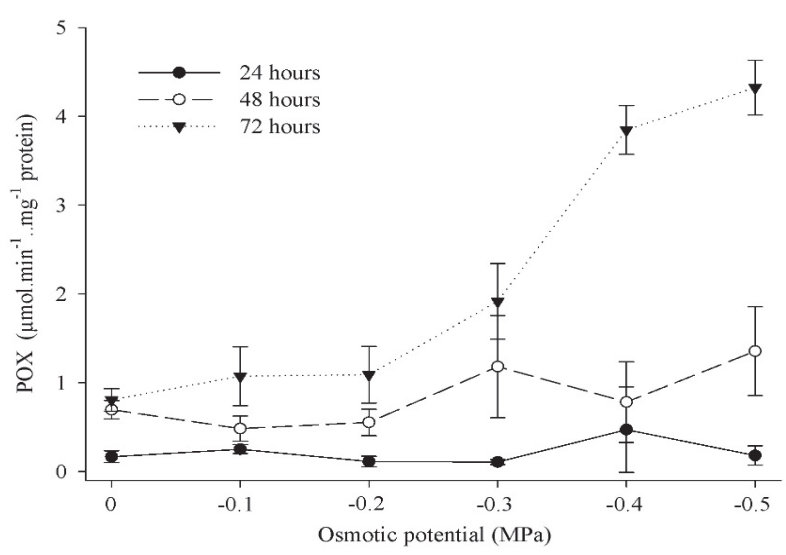

Figure 4. Peroxidase (POX) activity in melon seeds exposed to salt stress at different osmotic potentials and imbibition times. Bars: standard deviation. 
the other hand, Sevengor et al. (2011), by examining the effect of salt stress on pumpkin seedlings (using a similar condition of imbibition time of $72 \mathrm{~h}$ ), observed reduced activities of SOD.

The maximum CAT activity was observed at the osmotic potential of $-0.5 \mathrm{MPa}$ and $72 \mathrm{~h}$ of imbibition, being considered the highest stress level assessed. As observed for SOD, the CAT activity after $24 \mathrm{~h}$ and $48 \mathrm{~h}$ of imbibition was greater at $0.0 \mathrm{MPa},-0.1 \mathrm{MPa},-0.2 \mathrm{MPa}$ and $-0.3 \mathrm{MPa}$ (Figure 3). This can be explained by the fact that this enzyme is particularly important in the initial seedlings germination and growth stages, removing the $\mathrm{H}_{2} \mathrm{O}_{2}$ produced during the $\beta$-oxidation of fatty acids (Bewley et al. 2013).

Increased CAT activity in cucurbit seeds and seedlings under salt stress were recently reported for pumpkin (Sevengor et al. 2011), melon (Keling et al. 2013, Dantas et al. 2015) and cucumber (Fan et al. 2013), showing the importance of this enzyme in the defense mechanism against oxidative stress under these conditions.

Differently from the results found for SOD and CAT, the increased POX activity was proportional to the imbibition duration. From $-0.3 \mathrm{MPa}$ to $-0.5 \mathrm{MPa}$, with $72 \mathrm{~h}$ of imbibition time, it was observed an increased POX activity (Figure 4). Peroxidases oxidize organic substrates, having $\mathrm{H}_{2} \mathrm{O}_{2}$ as electrons acceptor molecule, resulting in water release (Mittler 2002), and an enhanced activity of these enzymes may indicate a protective role against salt stress (Harter et al. 2014). However, like other antioxidant enzymes, POX may have different activity patterns.

Fan et al. (2013) observed that the POX activity was not affected in salt-stressed cucumber seeds. On the other hand, also evaluating salt stress in squash (Cucurbita pepo) seeds, Harter et al. (2014) observed significant increases in this enzyme activity. Peroxidases act in cooperation with CAT in removing excessive $\mathrm{H}_{2} \mathrm{O}_{2}$ in the cell, and the activity of these enzymes depends mainly on the stress intensity, duration and nature (Sharma et al. 2012).

It is important to emphasize that reactive oxygen species are normal byproducts of the aerobic metabolism, like respiration (Mittler 2002). As an example, $\mathrm{H}_{2} \mathrm{O}_{2}$, in adequate levels in the cells, is beneficial to diverse metabolic processes, such as cell signaling in response to stresses, tissues restoration and seeds germination (Rhee 2006,
Gill \& Tuteja 2010). Thus, the antioxidant enzymes activity is common even under non-stress conditions, as observed at $0.0 \mathrm{MPa}$, for all enzymes analyzed (Figures 3, 4 and 5).

The differences observed in the antioxidant enzymes activities, considering the different osmotic potentials and imbibition times, indicate various factors that interfere with the activity of these enzymes or favor it, such as the osmotic and/or toxic effects caused by excessive salt concentrations and the balance between the levels of reactive oxygen species and the antioxidant systems, in the prevention of cell oxidative stress (Sivritepe et al. 2008, Kavas et al. 2013).

In summary, besides concentration, the effects of salt stress depend on the time of exposure to $\mathrm{NaCl}$, genotype and associated environmental factors (Hasanuzzaman et al. 2013). The variations observed with respect to salt stress tolerance mechanisms, in melon plants, are important for studies aiming at the genetic control of characteristics assessed in saline environments (Maia et al. 2011).

\section{CONCLUSIONS}

1. $\mathrm{NaCl}$-induced stress reduces the germination rate of melon seeds, particularly at osmotic potentials of $-0.2 \mathrm{MPa}$ and lower;

2. There is a significant increase in the activity of SOD, CAT and POX antioxidant enzymes in melon seeds under salt stress, especially after $48 \mathrm{~h}$ of exposure.

\section{REFERENCES}

ANDERSON, M. D.; PRASAD, T. K.; STEWART, C. R. Changes in isozyme profiles of catalase, peroxidase, and glutathione reductase during acclimation to chilling in mesocotylus of maize seedlings. Plant Physiology, v. 109, n. 4, p. 1247-1257, 1995.

BEAUCHAMP, C.; FRIDOVICH, I. Superoxide dismutase: improved assays and an assay applicable to acrylamide gels. Analytical Biochemistry, v. 44, n. 1, p. 276-287, 1971.

BEWLEY, J. D. et al. Seeds: physiology of development, germination and dormancy. 3. ed. New York: Springer, 2013.

BLUM, A. Plant-water relations, plant stress and plant production. In: BLUM, A. Plant breeding for water-limited environments. Tel Aviv: Springer, 2011. p. 11-52. 
BRADFORD, M. M. A rapid and sensitive method for the quantitation of microgram quantities of protein utilizing the principle of protein-dye binding. Analytical Biochemistry, v. 72, n. 1-2, p. 248-254, 1976.

BRASIL. Ministério da Agricultura, Pecuária e Abastecimento. Regras para análise de sementes. Brasília, DF: SNAD/DNDV/CLAV, 2009.

CELIKKOL-AKCAY, U. et al. Drought-induced oxidative damage and antioxidant responses in peanut (Arachishy pogaea L.) seedlings. Plant Growth Regulation, v. 61, n. 1, p. 21-28, 2010.

CHANCE, B.; MAEHLEY, A. C. Assay of catalases and peroxidases. Methods in Enzymology, v. 2, n. 2, p. 764$775,1955$.

DANTAS, B. F. et al. Respiration and antioxidant enzymes activity in watermelon seeds and seedlings subjected to salt and temperature stresses. American Journal of Experimental Agriculture, v. 7, n. 2, p. 70-77, 2015.

DAS, A. B. Bio prospecting and genetic engineering of mangrove genes to enhance salinity tolerance in crop plants. In: JAIN, S. M.; GUPTA, S. D. Biotechnology of Neglected and Underutilized Crops. New York: Springer, 2013. p. 385-456.

DEL LONGO, O. T. et al. Antioxidant defenses under hyperoxygenic and hyperosmotic conditions in leaves of two lines of maize with differential sensitivity to drought. Plant and Cell Physiology, v. 34, n. 7, p. 1023-1028, 1993.

FAN, H. F. et al. Effects of nitric oxide on the germination of cucumber seeds and antioxidant enzymes under salinity stress. Acta Physiologiae Plantarum, v. 35, n. 9, p. $2707-$ 2719, 2013.

GIANNOPOLITIS, C. N.; RIES, S. K. Superoxide dismutases. Plant Physiology, v. 59, n. 2, p. 309-314, 1977.

GILL, S. S.; TUTEJA, N. Reactive oxygen species and antioxidant machinery in abiotic stress tolerance in crop plants. Plant Physiology and Biochemistry, v. 48, n. 12, p. 909-930, 2010.

HARTER, L. S. et al. Salinidade e desempenho fisiológico de sementes e plântulas de mogango. Horticultura Brasileira, v. 32, n. 1, p. 80-85, 2014.

HASANUZZAMAN, M.; NAHAR, K.; FUJITA, M. Plant response to salt stress and role of exogenous protectants to mitigate salt-induced damages. In: AHMAD, P. et al. (Eds.). Ecophysiology and responses of plants under salt stress. New York: Springer, 2013. p. 25-87.

HAVIR, E. A.; MCHALE, N. A. Biochemical and developmental characterization of multiple forms of catalase in tobacco leaves. Plant Physiology, v. 84, n. 2, p. 450-455, 1987.
KAR, M.; MISHRA, D. Catalase, peroxidase, and polyphenoloxidase activities during rice leaf senescence. Plant Physiology, v. 57, n. 2, p. 315-319, 1976.

KAVAS, M. et al. Effect of drought stress on oxidative damage and antioxidant enzyme activity in melon seedlings. Turkey Journal of Biology, v. 37, n. 4, p. 491498, 2013.

KELING, H. et al. Influence of selenium on growth, lipid peroxidation and antioxidative enzyme activity in melon (Cucumis melo L.) seedlings under salt stress. Acta Societatis Botanicorum Poloniae, v. 82, n. 3, p. 193-197, 2013.

LÄUCHLI, A.; GRATTAN, S. R. Plant growth and development under salinity stress. In: JENKS, M. A. et al. Advances in molecular breeding toward drought and salt tolerant crops. Helsinki: Springer, 2007. p. 1-32.

MAIA, L. K. R. et al. Efeito da salinidade sobre a germinação de acessos de meloeiro. Jornal da Sociedade Interamericana de Horticultura Tropical, v. 53, n. 1, p. 127-131, 2011.

MARCOS-FILHO, J. Fisiologia de sementes de plantas cultivadas. Londrina: Abrates, 2015.

MITTLER, R. Oxidative stress, antioxidants and stress tolerance. Trends in Plant Science, v. 7, n. 9, p. 405-410, 2002.

NAKAGAWA, J. Testes de vigor baseados no desempenho das plântulas. In: KRZYZANOWSKI, F. C.; VIEIRA, R. D.; FRANÇA NETO, J. B. (Eds.). Vigor de sementes: conceitos e testes. Londrina: Abrates, 1999. p. 2-1-2-24.

PEIXOTO, P. H. P. et al. Aluminum effects on lipid peroxidation and on activities of enzymes of oxidative metabolism in sorghum. Revista Brasileira de Fisiologia Vegetal, v. 11, n. 3, p. 137-143, 1999.

RHEE, S. G. $\mathrm{H}_{2} \mathrm{O}_{2}$, a necessary evil for cell signaling. Science, v. 312, n. 5782, p. 1882-1883, 2006.

SECCO, L. B. et al. Germinação de sementes de melão (Cucumis melo L.) em condições de estresse salino. Revista Verde de Agroecologia e Desenvolvimento Sustentável, v. 4, n. 4, p. 129-135, 2010.

SECKIN, B. et al. The role of antioxidant defense systems at differential salt tolerance of Hordeum marinum Huds. (sea barley grass) and Hordeum vulgare L. (cultivated barley). Environmental and Experimental Botany, v. 69, n. 1, p. 76-85, 2010.

SEVENGOR, S. et al. The effect of salt stress on growth, chlorophyll content, lipid peroxidation and antioxidative enzymes of pumpkin seedling. African Journal of Agricultural Research, v. 6, n. 21, p. 4920-4924, 2011. 
SHARMA, P. et al. Reactive oxygen species, oxidative damage, and antioxidative defense mechanism in plants under stressful conditions. Journal of Botany, v. 1, n. 1, p. 1-26, 2012.

SIVRITEPE, N. et al. $\mathrm{NaCl}$ pre-treatments mediate salt adaptation in melon plants through antioxidative system. Seed Science and Technology, v. 36, n. 2, p. 360-370, 2008.

SOARES, M. M. et al. Estresse hídrico e salino em sementes de soja classificadas em diferentes tamanhos. Pesquisa Agropecuária Tropical, v. 45, n. 4, p. 370-378, 2015.

TORRES, S. B. Germinação e desenvolvimento de plântulas de melancia em função da salinidade. Revista Brasileira de Sementes, v. 29, n. 3, p. 77-82, 2007.

TORRES, S. B.; VIEIRA, E. L.; MARCOS FILHO, J. Efeitos da salinidade na germinação e no desenvolvimento de plântulas de pepino. Revista Brasileira de Sementes, v. 22, n. 2, p. 39-44, 2000.

WAHID, A. et al. Germination of seeds and propagules under salt stress. In: PESSARAKLI, M. (Ed.). Handbook of plant and crop stress. 3. ed. Boca Raton: CRC Press, 2011. p. 321-337.

YACOUBI, R. et al. Proteomic analysis of the enhancement of seed vigour in osmoprimed alfalfa seeds germinated under salinity stress. Seed Science Research, v. 23, n. 2, p. 99-110, 2013.

YAO, Z. et al. Developmental and seed aging mediated regulation of antioxidative genes and differential expression of proteins during pre- and post-germinative phases in pea. Journal of Plant Physiology, v. 169, n. 15, p. 1477-1488, 2012.

ZHANG, H. et al. Influence of salinity and temperature on seed germination rate and the hydrotime model parameters for the halophyte, Chloris virgata, and the glycophyte, Digitaria sanguinalis. South African Journal of Botany, v. 78, n. 1, p. 203-210, 2012.

ZHANG, H. J. et al. Melatonin promotes seed germination under high salinity by regulating antioxidant systems, $\mathrm{ABA}$ and $\mathrm{GA}_{4}$ interaction in cucumber (Cucumis sativus L.). Journal of Pineal Research, v. 57, n. 3, p. 269-279, 2014. 